live, the long, loving, contemplative gaze on the real is always a possibility.

The $12^{\text {th }}$ century Cistercian monk, Saint Bernard of Clairvaux, once said; "I have discovered that you will find far more in the forests than in books; trees and stones will teach you that which you cannot learn from any master." Turn a discerning eye to the crea- tures and processes that surround you and you will enter a world of marvel and beauty. Let Natural Grace be your companion and guide.

JOHN MCCARTHY, S.J.

St. Mark's College, University of British Columbia, 5935 Iona Drive, Vancouver, British Columbia V6T 1J7 Canada

\title{
Tales from the Underground: A Natural History of Subterranean Life
}

By David W. Wolfe. 2001. Perseus Publishing, 5500 Central Avenue, Boulder, Colorado 80301 USA. 221 pages. $\$ 27.50$

Tales from the Underground is a MUST read for any naturalist interested in what's happening under our feet. The book is engaging, well-written, and filled with information that is truly awesome.

In the introduction, author David Wolfe, Associate Professor of Plant Ecology at Cornell University, invites his "subterranean-impaired" readers to use their imaginations and join him on a dive trip into a mysterious world scientists are only just beginning to understand. Wolfe launches the journey with a description of the various soil "profiles", also known as layers or horizons, and the organisms that inhabit them. Some of the life forms I had never heard of; others I had never thought about in the way Wolfe describes them.

Take plants, for example. Wolfe starts by praising their display of foliage aboveground. He then points out that plants are unique because they simultaneously inhabit both the surface and sub-surface realms. $\mathrm{He}$ calls them the "great mediators between the two realms", and explains their functions both above and below the ground, with a focus on their buried other half: roots.

In Part I of the book, "Ancient Life", Wolfe covers a lot of ground. He discusses theories of the origin of life, the basic elements necessary for the evolution of life, Earth's advantage as a life-generating planet, and speculation pointing to the subterranean realm as the place where life began. He also introduces "extremophiles", creatures that live in severe conditions thousands of feet underground, where pressure and temperatures are extraordinarily high, and where there is neither light nor oxygen - the postulated setting for the beginning of life.

Wolfe also describes Carl Woese's discovery of the amazing genetic diversity of these extremophiles, and discusses how that discovery changed the universal tree of life. Originally composed of bacteria, plants, fungi, animals and protozoa, the tree of life now has only three branches - bacteria, archaea (the extremophiles) and eukarya (with plants and animals as two small twigs). It's a fascinating and humbling picture.

In Part II, "Life Support for Planet Earth", Wolfe dedicates an entire chapter to Charles Darwin and the lasting influence of the renowned scientist's meticulous and painstaking work. Wolfe also portrays certain inconspicuous subterranean creatures and the important roles they play in cycling essential elements and facilitating the flow of energy - processes that sustain life on this planet. He also discusses the dual roles played by soil with respect to plant and animal diseases; some soil microbes cause diseases, while others provide powerful antidotes.

The third part of the book, "The Human Factor", describes the enormous footprint of Homo sapiens on the planet. Wolfe tells the sobering, appalling story of human activities and their devastating impacts on wildlife such as prairie dogs, black-footed ferrets, and burrowing owls, and on soil integrity in general. Descriptions of soil erosion and the 1930s dust bowl crisis are particularly gripping.

Yet despite the doom and gloom, Wolfe ends on an optimistic note. The very last sentence of the book reads, "It is my hope that as more of us become aware of the life beneath our feet, and its relevance to our well-being, we will be inclined to work together to maintain the biological integrity of the underground, and preserve some of what we find there for future generations" - words we have heard before in one form or another, but good to see repeated in this context.

Tales from the Underground is David Wolfe's first book, and I hope it isn't his last. He has a pleasant and easy-to-read writing style, and manages to convey scientific concepts so that even a non-scientific type like me can understand. Tales from the Underground has found a permanent place on my bookshelves.

\section{R. SANDER-REGIER}

RR5 Shawville, Quebec J0X 2Y0 Canada 